\title{
Pollution Due to Oil Spills in Marine Environment And Control Measures
}

\author{
Dr.R.Giri Prasad ${ }^{1}$, Associate Professor, \\ Mr.M.V.V.S.Anuprakash ${ }^{2}$, Assistant Professor \\ Dept. of Petroleum Technology, Aditya Engineering College, Surampalem - 533437, Andhra Pradesh, India
}

\begin{abstract}
In the present world population is 7 billion with a growth rate of $1.1 \%$ per year. The twentieth century world saw a rapid increase in fossil fuel consumption. The energy percentage of fossil fuels are $80 \%$ (Oil \& Gas 63\%, Coal: 27\%) of the total energy. World crude oil demand grew at an average rate of $1.76 \%$ per year. Oil and gas consumption is essential to sustaining economic growth in the industrialized world and is key to progress in nations working their way toward prosperity. The oil and gas industry is a truly global industry, it is extended from Alaska to Australia and Peru to China, and in every habitat from Arctic to desert, from tropical rainforest to temperate wood land, from mangrove to offshore. From 2000 to 2010, global oil demand grew by $13 \%$ and production increasing from 76.6 million barrels per day to $86.3 \mathrm{mbpd}$. The IEA (International Energy Association) estimates the global oil demand to reach 90 mbpd by 2016 mainly on the back of demand from non-OECD (Organization of Economic Co-Operation Development) countries.

Above all are one side of the coin, the other side is oil and gas industry is one of the top environmental destructive industry. From prospecting to production and refining to distribution, every stage it pollutes the air, soil and water. It damages the ecological balance and economy. This paper mentions the details of the pollution due to oil spills in marine environment. Marine oil spill is a serious consequence of off-shore oil drilling, blowouts, pipeline breakages, ship collusions or grounding and over filling of tankers. Oil spills damage the marine flora and fauna. More than 3 million metric tonnes of oil contaminates the sea waters every year. They have destructive effect on coastal environment. The spills are controlled by booms, skimmers, sorbents, dispersants and controlled burning processes.
\end{abstract}

Keywords: World Oil Industry, Oil Spill, Environmental Impact, Controlling Measures

\section{History of Oil Industry}

The traditional view of the oil industry is that it started in the USA in 1859, Not true, the oil seeps at Baku (in present - day Azerbaijan) flowed freely for many centuries before year one. They played major role around $600 \mathrm{BC}$ in the Zoroastrian religion of Persia and India. Credit for the first drilled oil well goes to the Chinese in the year 347 AD. Oil street lights appeared in Cordoba around 900, London in 1414, and Paris in 1524. Sir Thomas Shirley presented a paper to the Royal Society in 1658 on natural gas flows in Britain. In 1739, V.I.Veitbrecht published an article name "About Oil" in the Russian Scientific magazine "Primechaniya na Vedemosti" where he described the Baku area oil wells and provided a plan of the oil and gas fields. This may be the first technical paper with a reservoir description. Azerbaijan claims the first drilled well in the modern era at Bibi - Heybat, a suburb of Baku on the Caspian Sea, in 1846. The first drilled oil wells in Europe were located near Bucharest in Romania in 1857 but Poland makes the same claim for 1854 at Bobrka. The completion of the first commercial oil well in North America occurred in 1858 at Oil Springs, Lambton County Ontario. Until 1901, Baku's annual oil output exceeded that of the USA by as much as $25 \%$.

\section{World Oil Reserves}

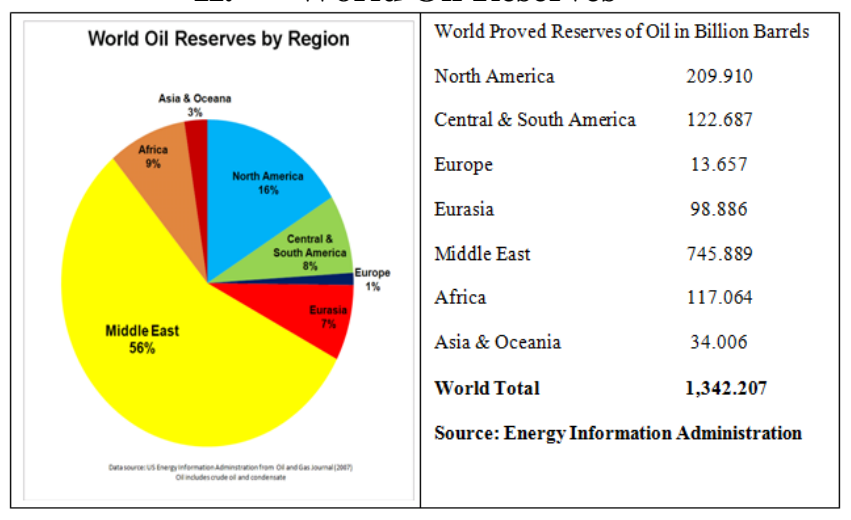




\section{Production \& Demand}

Oil is the primary source driver for the world OECD and non-OECD nations. We get thousands of every day products, from medicines to plastics and fibers to clothing from crude. And, of course, oil gives us gasoline, as well as diesel and jet fuel. Oil literally drives our economies. It touches almost every aspect of our lives. Moreover, there are no affordable substitutes for most of the products we get from oil. The demand for oil is always much higher than what it actually produced. Presently world daily oil supply is $86.6 \mathrm{mbpd}$. In 2030 the world oil demand reaches to $105.5 \mathrm{mbpd}$. The global oil and gas industry value in 2009 was $\$ 2,119.3$ billion. In 2014 , the global oil and gas market is forecast to have a value of $\$ 3,192.8$ billion. In 2014 , the global oil \& gas market is forecast to have a volume of 41 billion BOE (Barrels of Oil Equivalent), an increase of 10.2\%. Crude oil is the largest segment of the global oil and gas market, accounting for $64.1 \%$ of the market's total value.

\section{Pollution Due to Oil Spills in Marine Environment}

Pollution is the introduction of substances into the environment that alter its physical, chemical and biological properties in such a way that is harmful to living organisms. In this circumstance, the substances are termed as pollutants. Energy consumption is a primary source of pollution and energy production is a primary source of environment destruction. Oil and Gas industry is one of largest money earning industry, at the same time it is major dirtiest and environment destructive industry on the planet earth. There are more than 40,000 oil \& gas fields all sizes in the world (BP statistical review, 2006). There is tremendous technological advancements come in oil industry from prospecting at great oceanic depths to distribution to customer in retail petrol bunks. But, Oil is the most common pollutant in the oceans. More than 3 million metric tons of oil contaminates the sea every year. From 1940s Greenpoint Oil Spill to recent Deepwater Horizon oil spill at sea water pollutes the marine environment.

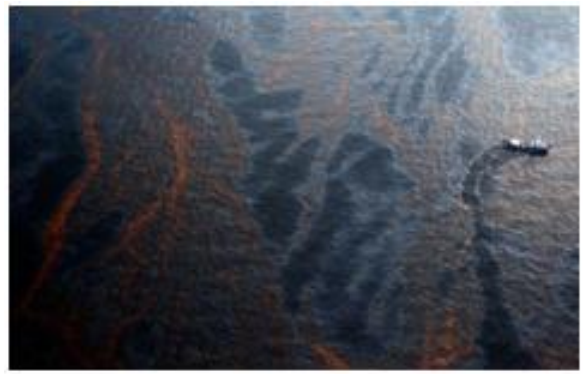

Figure.1 (Oil Slick)

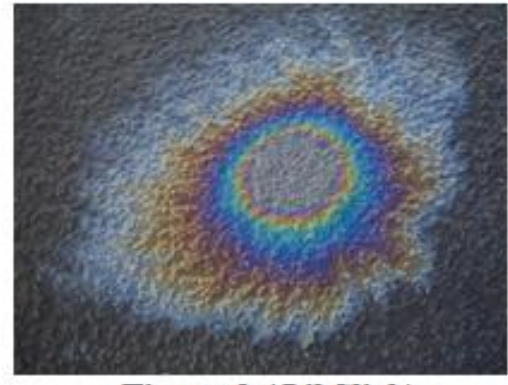

Figure.2 (Oil Slick)

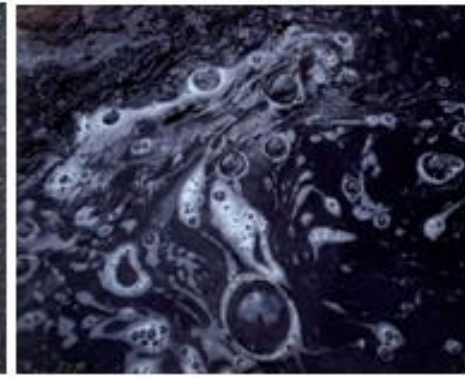

Figure.3 (Oil Slick)

An oil spill is unintentional release of liquid petroleum hydrocarbons in to the environment due to human activity or natural disaster. The term often refers to marine environment oil spills, where oil is released into the ocean or coastal waters

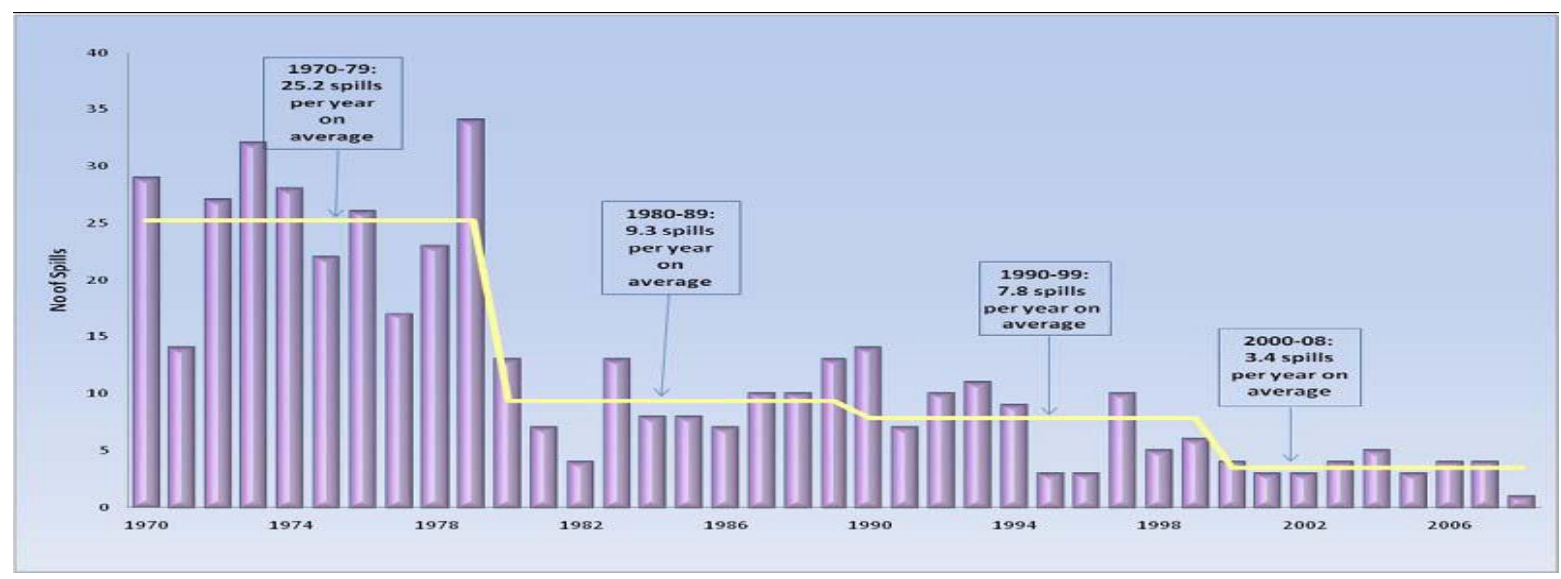

Figure.4 Number of Spill over 700 tonnes (Source: ITOPF)

Major factors of oil to the marine environment:

\begin{tabular}{|l|c|}
\hline Factor & $\%$ \\
\hline Industrial wastes reach the sea. & $37 \%$ \\
\hline Oil vessels during transportation & $33 \%$ \\
\hline
\end{tabular}




\begin{tabular}{|l|c|}
\hline Accidents involving tankers & $12 \%$ \\
\hline During Exploration Operations & $2 \%$ \\
\hline Natural sources like fissures from sea bed & $7 \%$ \\
\hline Absorbed from atmosphere & $9 \%$ \\
\hline
\end{tabular}

Source: Australian Institute of Petroleum

\subsection{Rig Fires:}

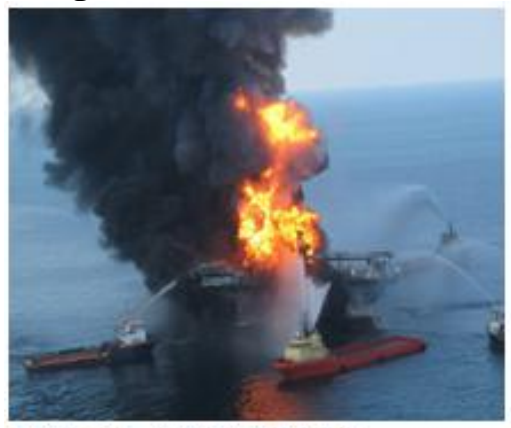

Figure.5 (Rig on Fires)

\section{Causes of Oil Spills at Off-Shore}

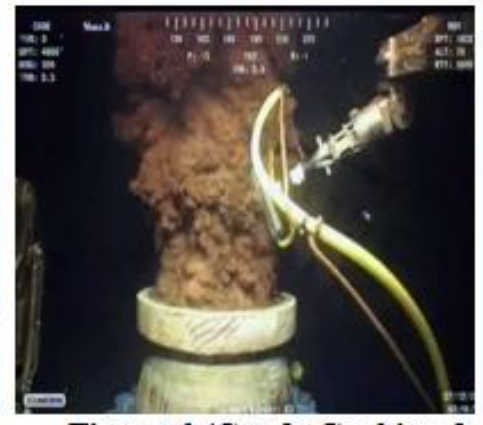

Figure.6 (Crude Gushing from well)

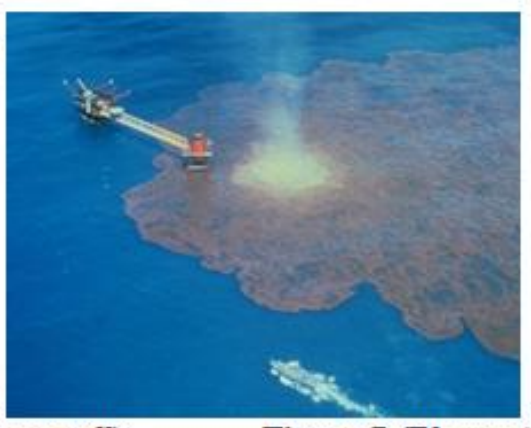

Figure.7 (Blowout)

These are usually associated with unexpected blowouts of liquid and gaseous hydrocarbons from the well as a result of encountering zones with abnormally high pressure. These types of spills are considerable, primarily due to their regularity leading, ultimately, to chronic impacts on the marine environment.

\subsection{Crude oil \& Petroleum Products Transportation:}

In 2008, the share of tanker trade in the total world seaborne trade amounted to $33.7 \%$. World shipments of tanker cargoes reached 2.75 Billion Tonnes, two thirds of which were crude oil. Crude oil seaborne shipments are increasing $1.1 \%$ per year. World shipments of petroleum products are increased by $2.7 \%$, estimate to reach 915.3 Million Tonnes. Developed regions accounted for $41.0 \%$ of world petroleum products loaded, and $56.1 \%$ of world petroleum products unloaded. Daily 40 to 45 Million Barrels of oil is transported by tankers.

Most of the oil spills occurred crude oil transportation. The Very Large Crude Carriers (VLCCs), Ultra Large Crude Carriers (ULCC), Suezmax and Aframax vessels (above 100,000 DWT) transport crude oil, whereas smaller vessels can be specially outfitted to also carry refined petroleum products. A 300,000 (DWT) VLCC can carry 2 million barrels of crude oil, a Suezmax can carry 1 million barrels of crude oil and an Aframax about 800,000 barrels of crude oil.

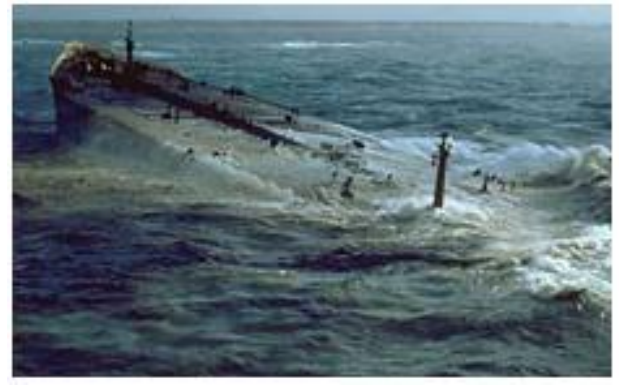

Figure.8 (Crude Oil Tanker)
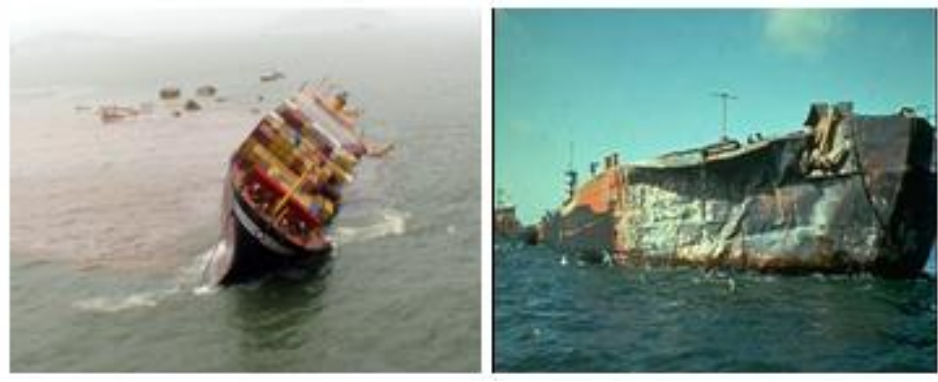

Figure.10 (Damaged Tanker)

Generally oil spill occurs, if the equipment breaks down or failure, the tanker may get stuck on shallow land. When they start to drive the tanker again, they can put a hole in the tanker causing it to leak oil in to the sea. The spill happen when tanker colloid with others ship or tanker, aground on reef, exploded due to fire, lightering accidents, hull damage and bilge pumping from ships. Sometimes the tankers or vessels hit the offshore installations. Disasters (like hurricanes) may cause an oil spill, too. If a hurricane was a couple of miles away, the winds from the hurricane could cause the oil tanker to flip over, pouring oil out.

\subsection{Storage:}

Under water storage tanks for storing of hydrocarbons are necessary element of many off-shore oil and gas fields. They are built near the platform foundations or anchored in semi submerged position in the sea area. 
Sometimes anchored tankers are used for this purpose as well. Risk exists of damaging the underwater storage tanks, especially during tanker loading operations or under severe weather conditions.

\subsection{Pipelines:}

Complex and extensive systems of underwater pipelines have a total length of thousands of kilometers. They carry oil, gas, condensate, and their mixtures from off-shore installations to onshore terminals and processed crude from onshore refineries to off-shore storage tanks (SPM). These pipelines are among the main factors of environmental risk during offshore oil developments, along with tanker transportation and drilling operation. They range from material defects, poor welding and joints and pipe corrosion due to ground erosion, and encountering ship anchors and bottom trawls. The other factors for oil spills are War between countries, Illegal dumping of waste oil by industries and Terrorist activities.

\section{Oil Spill Behavior}

When oil is spilled in the ocean, it initially spread in the water (primarily on the surface), depending on its relative density and composition. The oil slick formed may remain cohesive, or may break up in the case of rough seas. Waves, water currents, and wind force the oil slick to drift over large areas. Only ten minutes after a spill of 1 tonne of oil, the oil can disperse over a radius of $50 \mathrm{~m}$, forming a slick 10 -mm thick. The slick gets thinner (less than $1 \mathrm{~mm}$ ) as oil continues to spread, covering an area of up to $12 \mathrm{~km}^{2}$ [Ramade, 1978].

\section{Impacts on Marine Environment}

There is no clear relationship between the amount of oil spilled in the marine environment and the likely impact on wildlife. A smaller spill at the wrong time/wrong season and in a sensitive environment may prove much more harmful than a larger spill at another time of the year in another or even the same environment. Even small spills can have very large effects. The negative effects of on oil spill may eventually fade away, but in many cases it will be matter of several years, even decades, before an area or ecosystem has fully recovered from a spill that caused extensive damages. Every situation is unique and depending on the particular conditions and circumstances in that area, and on the characteristics of the spill. Some areas might recover in a matter of weeks, others will need up to 20 years.

In 1976, a spill estimated to have been less than 10 tonnes of crude oil, killed more than 60,000 longtailed ducks wintering in the Baltic Sea. This could be compared to the effects on seabirds in Alaskan waters from the approximately 40,000 tonnes of crude oil released from large Exxon Valdez oil spill in 1989, when an estimated 30,000 birds were oiled.

Australian Mari Time Authority (AMSA), mention the important factors related to the impact of oil spill.

- Spread of the oil slick

- Type of oil spilled, its movement and weathering characteristics

- Location of the spill

- Area of estuary, sea and foreshore impacted by oil

- Sensitivity of the regional environment, eg proximity to bird breeding colony

- Number of different habitats impacted, such as rock shore, beach, mangrove, wetland

- Timing of the incident (during seasonal breeding, bird migration)

- Nature, toxicity and persistence of the oil

- Variety of species at the spill location

\subsection{On Sea birds \& Sea Mammals:}

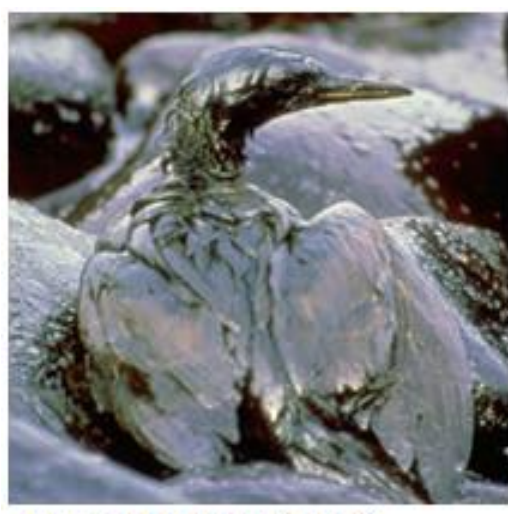

Figure.11 (Oiled Bird)

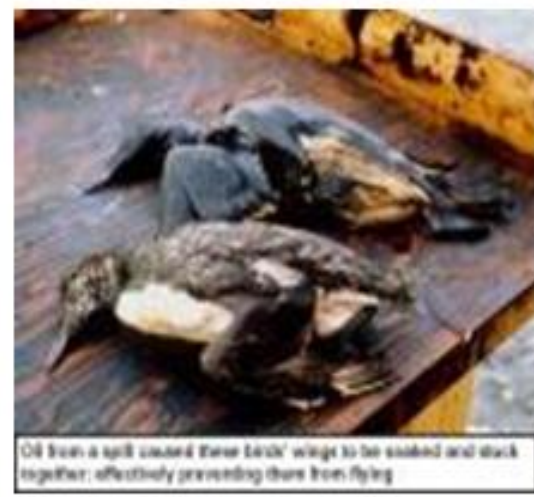

Figure.12 (Died Penguins)

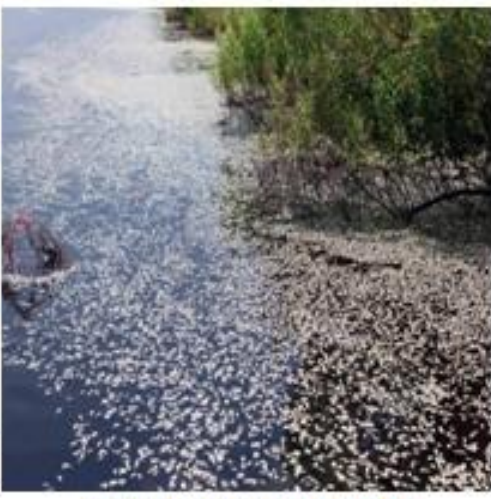

Figure.13 (Died Fish) 
Oil spill causes hypothermia effect on sea birds, dolphins, seals and sea otters. As oil mixes with water, it forms a substance called "mousse" which sticks to feathers and fur. A bird's feathers are filled with air space that act as insulation and keeps the bird warm. When a bird gets coated with oil, the feathers lose their insulating ability and the bird could die of hypothermia. Bird mortality occurs during most spills and in some major spills breeding colonies have been seriously depleted. There is scant evidence of spills causing long- term harm to populations, or of a spill tipping a marginal colony into permanent decline. Oil spills also cause increasing predation. Oil can weigh down feathers and fur, making it difficult for birds to escape from predators. If they are covered with enough oil, birds may actually drown. Animals can be poisoned or suffer internal damage from ingesting oil. Effects include ulcers and damage to red blood cells, kidneys, liver and to the immune system. Oil vapors can injure to eyes and lungs. If vapors are severe enough, marine mammals my become "sleepy" and drown.

\subsection{On Killer Whales:}

The oil may enter the whales blowhole. A blowhole is a hole to help them breath. Whales will rise up over the water to take a breath. If the blowhole is plugged with oil slick, the whale cannot breath. The main reason for whales dying because of a spill happens when they eat fish that swam through the oil, the whale will eat the oil along with the fish.

\subsection{Shallow Waters:}

Spill damage in shallow waters is most often caused by oil becoming mixed into the sea by wave action or by dispersant chemicals used inappropriately. In many circumstances the dilution capacity is sufficient to keep oil concentrations in the water below harmful levels, but in cases where light, toxic products have become dispersed, or in major incidents where heavy wave action has dispersed large volumes of oil close inshore, large kills of marine organisms such as shellfish and corals.

\subsection{Shorelines:}

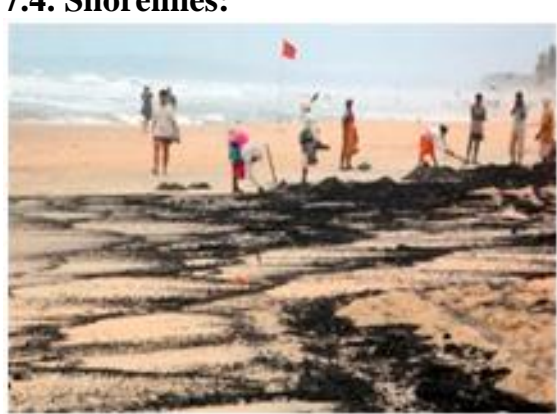

Figure.14 (Oiled Beach)

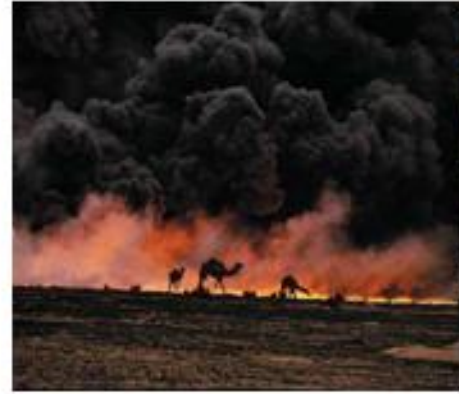

Figure.15 (Oiled Sediments)

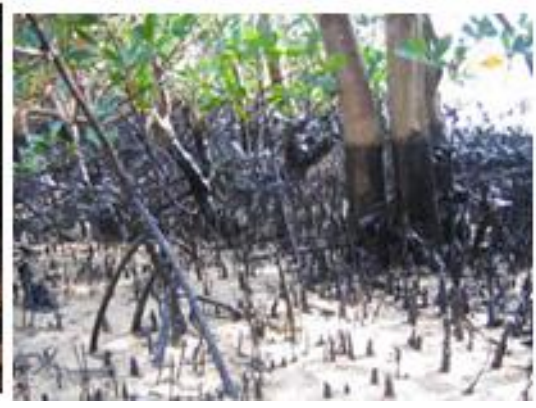

Figure.16 (Oiled Mangroves) S

Spill occurs near the shoreline, the greater the ecological damage. Coastal areas are home to more concentrated and diverse populations of marine life than at sea. Spills can also severely harm to turtle eggs and fish larva, causing deformities. Oil spills are also responsible for tainting algae, which perform a vital role in waterway ecosystems. If a spill isn't contained quickly, oil can lie beneath the surface of beaches and the sea, severely affecting marine organisms that burrow, such as crabs, for decades. Since these burrowing creatures are a food source for other animals, the cycle of poisoning can continue for many years.

\subsection{Mangrove Swamps:}

In tropical regions, mangrove swamps replace salt marshes and provide an extremely rich and diverse habitat as well as coastal protection and important nursery areas. Damage is more likely if oil smothers their breathing roots or if toxic oil penetrate the sediments. Where high mortality of trees occurs, in some cases including trees which are 50 ore more years old, natural recovery to a diverse and productive structure can take decades.

\section{Other Impacts Due to Oil Spill}

Industries that depend on seawater for their normal operation can also be adversely affected by oil spills. Power stations and desalination plants which draw large quantities of seawater can be particularly at risk, especially if their water intakes are located close to the sea surface, thereby increasing the possibility of drawing in floating oil. The normal operations of other coastal industries, such as shipyards, ports and harbours, can also be disrupted by oil spills and clean-up operations. 
A common cause of economic loss to fishermen is interruption to their activities by the presence of oil or the performance of clean-up operations. Sometimes this results from a precautionary ban on the catching and sale of fish and shellfish from the area.

Hazard to man health through eating contaminated sea foods and products. Decrease the aesthetic values due to unsightly slicks or oiled beaches.

\section{Largest Oil Spill in World History}

\begin{tabular}{|c|c|c|c|}
\hline Spill/Tanker & Location & Date & ${ }^{8}$ Tons of crude oil \\
\hline Kuwaiti oil fires & Kuwait & January, 1991 -November, 1991 & $136,000,000-205,000,000$ \\
\hline Kuwaiti oil lakes & Kuwait & January, 1991 -November, 1991 & $3,409,000-6,818,000$ \\
\hline Lakeview Gusher & United States, Kem County, Califomia & May 14,1910 -September, 1911 & $1,200,000$ \\
\hline Gulf War oil spill ${ }^{[d]}$ & Iraq, Persian Gulf and Kuwait & January 19, 1991 -January 28, 1991 & $818,000-1,091,000$ \\
\hline Deepwater Horizon & United States, Gulf of Mexico & April 20, 2010 -July 15, 2010 & $560,000-585,000$ \\
\hline Ixtoc I & Mexico, Gulf of Mexico & June 3, 1979 -March 23, 1980 & $454,000-480,000$ \\
\hline Atlantic Empress /Aegean Captain & Trimidad and Tobago & July 19,1979 & 287,000 \\
\hline Fergana Valley & Uzbekistan & March 2, 1992 & 285,000 \\
\hline Nowruz Field Platform & Iran, Persian Gulf & February 4, 1983 & 260,000 \\
\hline ABT Summer & Angola, $700 \mathrm{nmi}(1,300 \mathrm{~km} ; 810 \mathrm{mi})$ offshore & May 28, 1991 & 260,000 \\
\hline Castillo de Bellver & South Africa, Saldanha Bay & August 6, 1983 & 252,000 \\
\hline MT Haven & Italy, Mediterranean Seanear Genoa & April 11, 1991 & 144,000 \\
\hline Odyssey & Canada, $700 \mathrm{nmi}(1,300 \mathrm{~km} ; 810 \mathrm{mi})$ off Nova Scotia & November 10,1988 & 132,000 \\
\hline Sea Star & Iran, Gulf of Oman & December 19,1972 & 115,000 \\
\hline Irenes Serenade & Greece, Pylos & February 23,1980 & 100,000 \\
\hline Torrey Canyon & United Kingdom, Isles of Scilly & March 18, 1967 & $80,000-119,000$ \\
\hline Greenpoint Oil Spill & United States, Brooklyn,New York City & $1940-1950 \mathrm{~s}$ & $55,000-97,000$ \\
\hline
\end{tabular}

\section{Control Measures}

The recovery of the affected habitats and species following an oil spill will depend on the type of ecosystem, the vulnerability of the species and not least the climate of the region where the oil spill occurs. Generally, recovery will proceed faster in warmer climates and on rocky shores compared to cold climates and, for example, marshes. The long-term effects on deeper bottoms (i.e., if oil sinks and is absorbed in bottom sediments) is also a matter of concern.

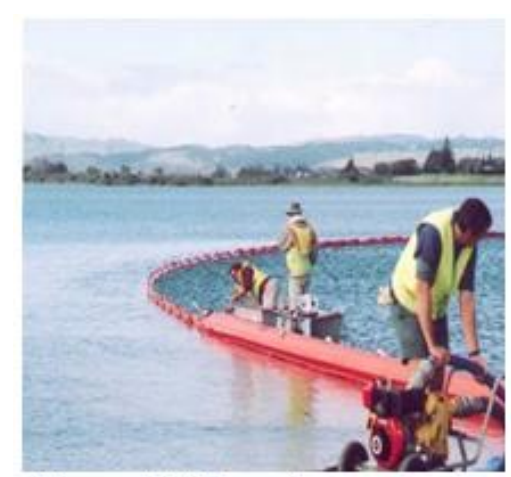

Figure.17 (Booms)

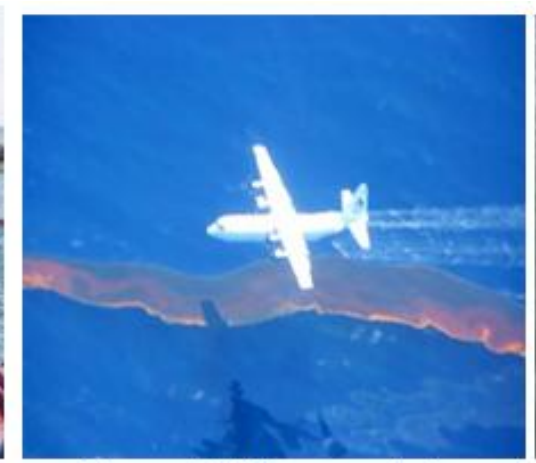

Figure.18 (Dispersants Spraying)

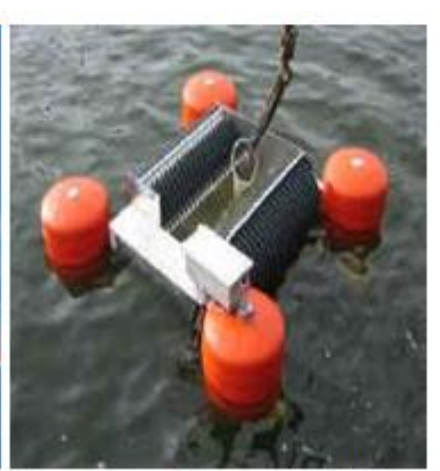

Figure.19 (Skimmer)

10.1. Booms: Booms are floating barriers used to clean oil from the surface of water and to prevent slicks from spreading. A boom can be placed around the tanker that is spilling oil. Booms collect the oil off the water. A boom nay be placed somewhere before oil spill. They can also be placed around an entrance to the ocean, like a stream. They also can be placed around a habitat with many animals living there. These booms absorb any oil that flows around it.

10.2.Skimmers: Skimmers are boats that can remove the oil off the water. Skimmers which use pumps or vacuums to remove oil as it float on water.

10.3. Sorbents: These are sponges that can collect the oil.

10.4. Dispersants: Dispersants act as detergents, clustering around oil globules and allowing them to be carried away in the water. This improves the surface aesthetically, and mobilizes the oil. Smaller oil droplets, scattered by currents, may cause less harm and may degrade more easily. But the dispersed oil droplets infiltrate into deeper water and can lethally contaminate coral. Recent research indicates that some dispersants are toxic to corals. An airplane can be used to fly over the water dropping chemicals into the ocean. The chemicals can break down the oil into the ocean. 
10.5. Bioremediation: In this process, bacteria or other microbes are introduced to the environment to help oxidize the oil. Unfortunately, this process can work slowly and is not very useful for large spills.

10.6. Controlled Burning: In this process burning the freshly spilled oil on sea surface with fireproof booms. Burning, only works under certain wind and weather conditions. This is the last option to decide, as this method causes air pollution.

10.7. Watch and wait: in some cases, natural attenuation of oil may be most appropriate, due to the invasive nature of facilitated methods of remediation, particularly in ecologically sensitive areas such as wetlands.

10.8. Solidifying: Solidifiers are composed of dry hydrophobic polymers that both adsorb and absorb. They clean up oil spills by changing the physical state of spilled oil from liquid to a semi-solid or a rubber-like material that floats on water. Solidifiers are insoluble in water, therefore the removal of the solidified oil is easy and the oil will not leach out. Solidifiers have been proven to be relatively non-toxic to aquatic and wild life and have been proven to suppress harmful vapors commonly associated with hydrocarbons such as Benzene, Xylene, Methyl Ethyl, Acetone and Naphtha. The reaction time for solidification of oil is controlled by the surface area or size of the polymer as well as the viscosity of the oil.

\section{Other Controlling Measures}

- All crude oil tankers must be double hulls or double bottoms.

- All tankers must have radar systems to improve navigations.

- Ship crew must be well trained and experienced \& strict fire safety regulations apply on board.

- Individual tanks within ships are limited in size so that spill should be smaller

- In more congested areas, vessels traffic control is used to reduce the risk of collusions

- Keeping the Navigation Informed Up-to-date information on changing weather conditions

- Interpretations of radar and satellite images and ice reconnaissance reports for sensitive coastal areas and inland routes.

- Computer - based video display that allows navigators to track the ship's course in relation to hazards, and warns the navigator of potential danger, both visually and audibly.

- Monitoring and control equipment on ships means that discharged oil - water mixtures can be traced back to the ship that way carrying the oil.

- Making the ship safer

- Strictly follow the Oil Pollution Act and Oil Spill Contingency Plan and International Maritime Organization Rules and National Oceanic and Atmospheric Administration guidelines.

\section{Conclusion}

Oil and Gas industry is truly global industry, it touches every corner of the globe. Worldwide developed and developing countries are majorly depending on the oil and gas industry for their economic growth and prosperity. In energy sector always there is huge gap between, production and demand of crude oil. After 1950s exploration operations are moved to greater depths of oceans. Off-shore hydrocarbon exploration operations are difficult and expensive compare to onshore. Major part of crude oil and petroleum products are transported between countries by sea born trading. For this use Very large crude carriers and Ultra large crude carriers. Single trip they can carry million barrels of crude oil. Sometimes accidents occur during drilling, transportation and off loading time, ultimately release of oil into the sea waters. Oil spills are very danger to the marine environment. The impact of oil spills can be far-reaching, from an environmental as well as a socioeconomic perspective. Marine and coastal habitats, wildlife species, recreational activities, local industry, and fisheries, are among the resources and sectors that can be negatively affected by oil spills. It affects seabirds, marine mammals, fish and shellfish, and bottom-living animals. It destroys beaches, destroys aquaculture, fisheries and deteriorates health effects from cleanup operations. The impacts of oil spill on marine environment sometimes stayed up to 20 years. Spills are controlled by various methods like booms, skimmers, dispersants, and bioremediation and controlled burning. All countries and crude oil vessels must follow the IMO, IOPA, OSCP, NOAA and MARPOL guidelines.

\section{References}

[1] Crain.E. R, P.Eng, 'A True History of Oil and Gas Development', Canadian Well Logging Society, 2000, P. 1-4

[2] J. Longwell, Harry. 'The Future of the Oil and Gas Industry: Past Approaches and New Challenges, World Energy, Vol.5, No.3, 2002, P.101

[3] Mansor shattri \& seyedeh zahra pourvakhshouri, Oil spill management via decision support system, 2003, P.1 - 9.

[4] Mandryk Wally, Lloyd's Marine Intelligence Unit, International Maritime Statistics Forum, 2009, P. 8 - 12.

[5] Nicolas Bornozis, A Review of Global Shipping Market, Greek Shipping is a Global Leader, P.6.

[6] Yoshioka Gary \& Madelyn Carpenter, Characteristics of Reported Inland and Coastal Oil Spills, P.4 - 11. 


\section{Bibliography}

1. International Energy Agency, 'Oil Market Report', 2010.

2. The International Tanker Owners Pollution Federation Limited, 'Oil Tankers Spill Statistics: 2008.

3. Organization of Petroleum Exporting Countries, World Oil Outlook, 2010.

\section{Websites}

1. www.oilandgasforum.net/news/library.htm

2. www.ipieca.org

3. www.ogp.org.uk/publications/index.asp

4. www.imo.org/inforesource/mainframe.asp?topic_id=64

5. www.ec.gc.ca/ee-ue/pub/pub_e.asp

6. www.response.restoration.noaa.gov/oilaids/reports.htm

7. www.gesamp.imo.org/publicat.htm

8. www.gpa.unep.org/documents/seas-docs.htm 